\title{
RECOMMENDED VALUES FOR THE DISTRIBUTION COEFFICIENT (KD) TO BE USED IN DOSE ASSESSMENTS FOR DECOMMISSIONING THE ZION NUCLEAR POWER PLANT
}

Terry Sullivan

June 9, 2014

Informal Report

\author{
Environmental \& Climate Sciences Department \\ Brookhaven National Laboratory \\ P.O. Box 5000 \\ Upton, NY 11973-5000 \\ www.bnl.gov
}




\section{DISCLAIMER}

This report was prepared as an account of work sponsored by an agency of the United States Government. Neither the United States Government nor any agency thereof, nor any of their employees, nor any of their contractors, subcontractors, or their employees, makes any warranty, express or implied, or assumes any legal liability or responsibility for the accuracy, completeness, or any third party's use or the results of such use of any information, apparatus, product, or process disclosed, or represents that its use would not infringe privately owned rights. Reference herein to any specific commercial product, process, or service by trade name, trademark, manufacturer, or otherwise, does not necessarily constitute or imply its endorsement, recommendation, or favoring by the United States Government or any agency thereof or its contractors or subcontractors. The views and opinions of authors expressed herein do not necessarily state or reflect those of the United States Government or any agency thereof. 


\section{Table of Contents}

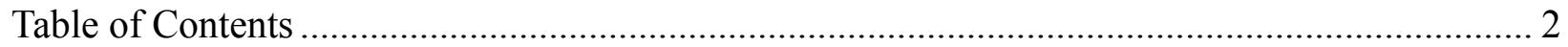

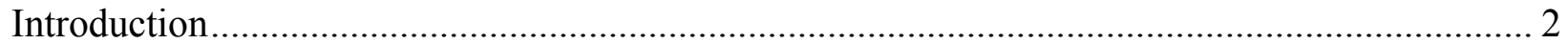

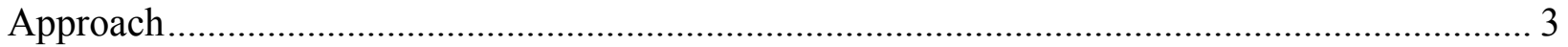

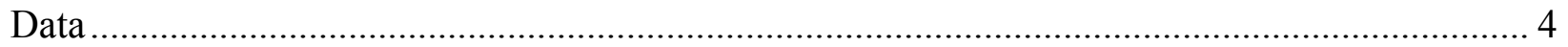

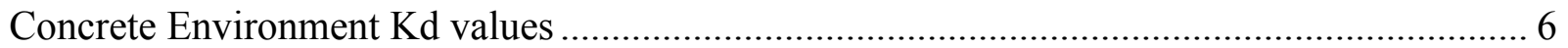

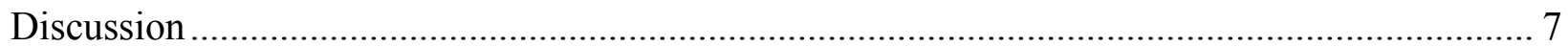

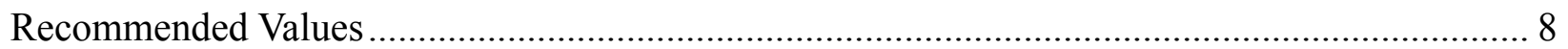

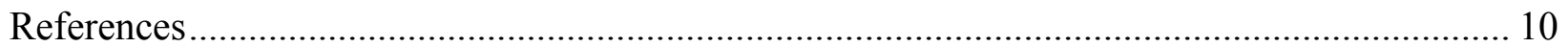

\section{List of Tables}

Table 1. Potential Radionuclides of Concern at the Zion Power Plant ....................................... 2

Table 2 Site-specific $K_{d}$ values $(\mathrm{ml} / \mathrm{g}$ ) for the Zion Nuclear Power Station ................................ 4

Table 3 Literature soil $\mathrm{K}_{\mathrm{d}}$ values for radionuclides of concern at Zion................................... 5

Table 4 Preferred distribution coefficients $\left(\mathrm{K}_{\mathrm{d}} \mathrm{ml} / \mathrm{g}\right)$ for cement concrete environments (Table 5.1 Krupka, 1998)...................................................................................................... 7

Table 5 Recommended $\mathrm{K}_{\mathrm{d}}$ values to be used in the basement fill model. ................................ 9

\section{Introduction}

ZionSolutions is in the process of decommissioning the Zion Nuclear Power Plant. The site contains two reactor Containment Buildings, a Fuel Building, an Auxiliary Building, and a Turbine Building that may be contaminated. The current decommissioning plan involves removing all above grade structures to a depth of 3 feet below grade. The remaining underground structures will be backfilled. The remaining underground structures will contain low amounts of residual licensed radioactive material. An important component of the decommissioning process is the demonstration that any remaining activity will not cause a hypothetical individual to receive a dose in excess of $25 \mathrm{mrem} / \mathrm{y}$ as specified in 10CFR20 Subpart E.

The compliance assessment requires prediction of the release and transport of contaminants to the hypothetical individual. Characterization studies by ZionSolutions have identified the following nuclides as being of potential concern (Table 1).

Table 1. Potential Radionuclides of Concern at the Zion Power Plant

\begin{tabular}{|l|l|l|l|l|l|}
\hline Radionuclides & Radionuclides & Radionuclides & Radionuclides & Radionuclides & Radionuclides \\
\hline H-3 & Co-60 & Tc-99 & Cs-137 & Eu-155 & Pu-241 \\
\hline C-14 & Ni-63 & Ag-108m & Pm-147 & Np-237 & Am-241 \\
\hline Fe-55 & Sr-90 & Sb-125 & Eu-152 & Pu-238 & Am-243 \\
\hline Ni-59 & Nb-94 & Cs-134 & Eu-154 & Pu-239/240 & Cm-243/244 \\
\hline
\end{tabular}


A key parameter in this assessment is the distribution coefficient $\left(\mathrm{K}_{\mathrm{d}}\right)$ which is a measure of the amount of the radionuclide that will sorb to the solid media (soil or backfill) in the subsurface environment. The exposure pathway of concern is the groundwater. Groundwater concentration has an inverse relationship with $\mathrm{K}_{\mathrm{d}}$. Thus a lower value of $\mathrm{K}_{\mathrm{d}}$ will provide higher groundwater concentrations and a more conservative prediction of dose. BNL (Yim, 2012, Milian, 2014) has conducted site-specific measurements on using local groundwater and samples of site soils and potential backfill materials to assess the $\mathrm{K}_{\mathrm{d}}$ value for the contaminants with the expected highest residual concentration (Fe-55, Co-60, Ni-63, Sr-90, and Cs-137) for ZionSolutions. However, there are several other radioactive contaminants (Table 1) that may be present at lower levels that will still require assessment to demonstrate that dose limits are not exceeded. This document reviews the existing literature to recommend a value for $\mathrm{K}_{\mathrm{d}}$ when site-specific numbers are not available.

Literature values for $\mathrm{K}_{\mathrm{d}}$ show that sorption strongly depends on the contacting media and the geochemical conditions. The backfill selected for disposal will therefore play a huge role in determining the choice of the $\mathrm{K}_{\mathrm{d}}$ value. A final decision has not been made on the backfill material at the Zion Power Plant. Materials under consideration include:

- Crushed concrete demolition debris

- Crushed cinder block

- Flowable grout

- Local sand

The concrete and cinder block would be obtained from the building materials removed to three feet below grade and would be free from residual radioactive contamination. Combinations of the above materials are also under consideration.

The first three materials are alkaline and will cause the $\mathrm{pH}$ to rise substantially above the local ambient conditions. Based on testing at BNL with materials supplied by ZionSolutions, the $\mathrm{pH}$ will initially increase to 10 or 11 for the cementitious materials and grout. Eventually, as the alkali is consumed by buffering reactions the $\mathrm{pH}$ will decrease. This is expected to take a minimum of several hundred years depending on the flow rate and buffering capacity of the surrounding soils. Several studies have found that $\mathrm{pH}$ is a key geochemical factor in controlling sorption. For this reason consideration must be given to the likely high $\mathrm{pH}$ conditions when selecting the $\mathrm{Kd}$ value to be used in modeling if a mixture of backfills is used.

\section{Approach}

The objective of selecting a $\mathrm{K}_{\mathrm{d}}$ value is to choose a value that is reasonably conservative with respect to projected groundwater dose (radionuclide concentrations). This requires a value that is likely to provide a lower bound for $\mathrm{K}_{\mathrm{d}}$. The value for $\mathrm{K}_{\mathrm{d}}$ strongly depends on the solid media that contacts the groundwater thus site-specific values are the most representative of actual conditions.

For radionuclides with site-specific data the media with the lowest measured $\mathrm{K}_{\mathrm{d}}$ was selected to provide this lower bound. For radionuclides without site-specific data the literature was reviewed to determine the range of $\mathrm{K}_{\mathrm{d}}$ values typically found in soils and found in cementitious (high $\mathrm{pH}$ ) environments. These Kds will be used for initial DUST-MS runs to determine 
groundwater concentrations at potential well locations. Depending upon the outcome they may be further refined with more site specific or literature data.

Baes and Sharp (Baes and Sharp 1983) were among the first to show that the Kd value for Cs and $\mathrm{Sr}$ is log-normally distributed in soils. They applied a log-normal distribution to all elements and this approach is widely used (Sheppard and Thibault, 1990; NRC, 1990). Sheppard and Thibault extended the concept of log-normal distribution to apply to a soil type (sand, loam, clay or organic). This concept is used in this report to determine the $25^{\text {th }}$ percentile value for $\mathrm{K}_{\mathrm{d}}$ in soils. The use of the $25^{\text {th }}$ percentile value has been performed in other decommissioning studies at Fermi (Dionne, 2009) and Humboldt Bay (Besson, 2013).

\section{Data}

Three types of data are used for the selection of an appropriate $\mathrm{Kd}$ for the backfill region at the Zion Nuclear Power Plant. These include site-specific values using local groundwater and soil or concrete samples from the site; literature values for soil environments; and literature values for concrete environments.

Site-specific $K_{d}$ data:

$\mathrm{K}_{\mathrm{d}}$ measurements were performed for ZionSolutions using site-specific groundwater and soil samples (clay, silt, native sand, and disturbed sand - native sand that was excavated during construction of the plant and backfilled around the plant) for six nuclides. Additionally potential backfill materials including two concrete samples (one from the Containment Building and one from the Crib House), two Cinder Block samples from the site, and one low density grout were tested using site-specific groundwater. The elements measured included $\mathrm{Fe}, \mathrm{Co}, \mathrm{Ni}, \mathrm{Sr}$ and $\mathrm{Cs}$. Table 2 presents the results of these measurements. Note isotopes of Cs and Ni found in Table 1 are also presented in Table 2 as isotopes will have the same chemical sorption properties.

Table 2 Site-specific $K_{d}$ values $(\mathrm{ml} / \mathrm{g})$ for the Zion Nuclear Power Station

\begin{tabular}{|c|c|c|c|c|c|c|c|c|}
\hline Radionuclide & $\begin{array}{c}\text { Site } \\
\text { Specific } \\
\text { Silt Kd }^{1} \\
\mathrm{ml} / \mathrm{g} \\
\end{array}$ & $\begin{array}{c}\text { Site } \\
\text { Specific } \\
\text { Silt } \\
\text { Clay }^{1} \text { Kd } \\
\mathrm{ml}^{\prime} \mathrm{g} \\
\end{array}$ & $\begin{array}{c}\text { Site } \\
\text { Specific } \\
\text { Disturbed } \\
\text { Sand Kd }^{1} \\
\mathrm{ml} / \mathrm{g} \\
\end{array}$ & $\begin{array}{c}\text { Site } \\
\text { Specific } \\
\text { Native } \\
\text { Sand Kd } \\
\text { ml/g }\end{array}$ & $\begin{array}{c}\text { Site Specific } \\
\text { Containment } \\
\text { Concrete }{ }^{1} \mathrm{Kd} \\
\mathrm{ml} / \mathrm{g}\end{array}$ & $\begin{array}{c}\text { Site } \\
\text { Specific } \\
\text { Crib } \\
\text { House } \\
\text { Concrete }^{1} \\
\text { Kd ml/g }^{2}\end{array}$ & $\begin{array}{c}\text { Site } \\
\text { Specific } \\
\text { Cinder } \\
\text { Block } \\
\mathrm{Kd}^{2} \\
\mathrm{ml} / \mathrm{g} \\
\end{array}$ & $\begin{array}{c}\text { Site } \\
\text { Specific } \\
\text { Low } \\
\text { Density } \\
\text { Grout Kd } \\
\text { ml/g }\end{array}$ \\
\hline Fe-55 & 8061 & 17288 & 2857 & 5579 & 16546 & 17288 & & \\
\hline $\mathrm{Ni}-59$ & 75 & 136 & 331 & 62 & 3438 & 8361 & 177 & 4,569 \\
\hline Co-60 & 1161 & 1161 & 1161 & 1161 & 1161 & 1161 & 223 & 1941 \\
\hline $\mathrm{Ni}-63$ & 75 & 136 & 331 & 62 & 3438 & 8361 & 177 & 4,569 \\
\hline Sr-90 & 2.3 & 5.7 & 3.4 & 2.3 & 10.4 & 18.5 & 23.5 & 11.8 \\
\hline Cs-134 & 527 & 3011 & 635 & 615 & 85 & 45 & 249 & 303 \\
\hline Cs-137 & 527 & 3011 & 635 & 615 & 85 & 45 & 249 & 303 \\
\hline
\end{tabular}

Y Yim, 2012

${ }^{2}$ Milian, 2014 
Numerous measurements of $\mathrm{K}_{\mathrm{d}}$ have been reported in the literature. Key compilations of this data include those by Baes and Sharp (Baes, 1983); Sheppard and Thibault (Sheppard, 1990), Yu (Yu, 1993), the U.S. Nuclear Regulatory Commission (NRC, 2000); and the International Atomic Energy Agency (IAEA, 2010). All of these documents provide statistical parameters to estimate the distribution. Literature values for $\mathrm{K}_{d}$ in soil media from selected sources are presented in Table 3. The first two columns are mean values for $\mathrm{K}_{\mathrm{d}}$ presented in (Yu, 1993 and IAEA 2012). For conservatism the $25^{\text {th }}$ percentile in the distribution from the reports (Sheppard, 1990 and NRC, 2000) are also reported in the Table 3. For the Sheppard data the log-normal distribution of the data for sand was used except for Nb-94 and Sb-125 which are the geometrics means because standard deviations were not provided in the Sheppard data. Other soil types were not included because sand, in most cases, has the lowest $K_{d}$ and the surrounding soil at Zion is primarily sand.

Table 3 Literature soil $K_{d}$ values for radionuclides of concern at Zion.

\begin{tabular}{|c|c|c|c|c|}
\hline Radionuclide & $\begin{array}{c}\text { (Yu, 1993) Sand } \\
\mathrm{Kd} \\
\mathrm{ml} / \mathrm{g} \\
\end{array}$ & $\begin{array}{c}\text { (IAEA 2010) } \\
\text { Tables } 12,14 \text { Sand or All } \\
\text { Soils } \mathrm{ml} / \mathrm{g}\end{array}$ & $\begin{array}{c}\text { (NRC, 2000) } \\
\text { 25th Percentile } \mathrm{ml} / \mathrm{g}\end{array}$ & $\begin{array}{l}\text { (Sheppard, 1990) } \\
\text { Sand 25th } \\
\text { Percentile } \mathrm{ml} / \mathrm{g}\end{array}$ \\
\hline $\mathrm{H}-3$ & & 1 & 0.0431 & 0.051 \\
\hline C-14 & 5 & & 1.24 & 1.76 \\
\hline Fe-55 & 220 & 320 & 34.3 & 39 \\
\hline $\mathrm{Ni}-59$ & 400 & 140 & 160 & 148 \\
\hline Co-60 & 60 & 640 & 42.9 & 9.2 \\
\hline $\mathrm{Ni}-63$ & 400 & 140 & 160 & 148 \\
\hline Sr-90 & 15 & 22 & 7.49 & 4.6 \\
\hline $\mathrm{Nb}-94$ & 160 & 170 & 44.6 & 164 \\
\hline Tc-99 & 0.1 & 0.23 & 0.0618 & 0.04 \\
\hline Ag-108m & 90 & & 52.6 & 27 \\
\hline Sb-125 & 45 & 17 & 43.4 & 45 \\
\hline Cs-134 & 280 & 530 & 92.5 & 51 \\
\hline Cs-137 & 280 & 530 & 93.4 & 51 \\
\hline $\mathrm{Pm}-147$ & & 450 & 94.8 & \\
\hline Eu-152 & & & 96.2 & \\
\hline Eu-154 & & & 95.2 & \\
\hline Eu-155 & & & 95.8 & \\
\hline $\mathrm{Np}-237$ & 5 & 35 & 3.75 & 1.30 \\
\hline Pu-238 & 550 & 400 & 268 & 174 \\
\hline $\mathrm{Pu}-239 / 240$ & 550 & 400 & 267.5 & 174 \\
\hline Pu-241 & 550 & 400 & 268 & 174 \\
\hline Am-241 & 1900 & 1000 & 177 & 333 \\
\hline Am-243 & 1900 & 1000 & 178 & 333 \\
\hline $\mathrm{Cm}-243 / 244$ & 4000 & 9300 & 1990 & 891 \\
\hline
\end{tabular}


The predictions at the $25^{\text {th }}$ percent level of the distribution for the NRC and Sheppard reports are similar. This is because the NRC data set for the distribution is based on, but not limited to the Sheppard data set.

\section{Concrete Environment Kd values}

The chemistry of the water will change from an initial value of greater than 11 down to the ambient $\mathrm{pH}$ in a crushed concrete environment. The convention of Bradbury and Sarott (1995) describing the three types of chemical environments that all cements progress through is used to understand the data. The following description of the environments has been abbreviated from the initial work by Krupka (Krupka, 1998)

- Environment I This environment occurs immediately after the cement hardens and is wetted by infiltrating water The cement pore water is characterized as having a high $\mathrm{pH}$ of $>12.5$, high ionic strength, and high concentrations of potassium and sodium resulting from the dissolution of alkali impurities in the clinker phases. Hydration is still continuing during Environment I with the formation of C-S-H (Calcium- Silicate Hydrate) and portlandite $\left[\mathrm{Ca}(\mathrm{OH})_{2}\right]$ The composition of the cement pore fluid is at equilibrium with portlandite during this time. Based on the modeling estimates this environment may last for the first 100 to 10,000 years.

Environment II During this period, the soluble salts of the alkali metals are all dissolved The $\mathrm{pH}$ of the cement pore water is controlled at a value of about 12.5 by the solubility of portlandite. The C-S-H and portlandite are the major solid phases present Environment II may last for a long time Its' duration depends on how much water percolates through the system to dissolve all the slightly soluble portlandite This environment may last from 100-10,000 years to $1,000-100,000$ years.

Environment III The concentration of portlandite has been reduced to such an extent by this period that the solubility of C-S-H now controls the $\mathrm{pH}$ of the cement pore fluid The C-S-H starts to dissolve incongruently with a continual decrease in $\mathrm{pH}$ At the end of this evolution, Environment III can be conceptualized as leaving only silica $\left(\mathrm{SiO}_{2}\right)$ as the solubility control for the pore fluid $\mathrm{pH}$. For the sake of simplicity, the final end point of Environment III can be considered somewhat analogous to the geochemical conditions of the "normal" ambient soil environment.

The important point of this discussion is that the cement will control the $\mathrm{pH}$ for hundreds to thousands of years. Thus, if cementitious materials are used for backfill material, a high $\mathrm{pH}$ environment will prevail and $\mathrm{K}_{\mathrm{d}}$ values are likely to be similar to those found in cement based materials. 
Table 4 Preferred distribution coefficients $\left(K_{d} \mathrm{ml} / \mathrm{g}\right)$ for cement concrete environments (Table 5.1 Krupka, 1998).

\begin{tabular}{|c|c|c|c|c|c|c|}
\hline & \multicolumn{2}{|c|}{ Environment I } & \multicolumn{2}{|c|}{ Environment II } & \multicolumn{2}{|c|}{ Environment III } \\
\hline & $\begin{array}{c}\text { Oxidizing } \\
\text { Conditions } \\
\end{array}$ & $\begin{array}{c}\text { Reducing } \\
\text { Conditions } \\
\end{array}$ & $\begin{array}{c}\text { Oxidizing } \\
\text { Conditions } \\
\end{array}$ & $\begin{array}{c}\text { Reducing } \\
\text { Conditions } \\
\end{array}$ & $\begin{array}{c}\text { Oxidizing } \\
\text { Conditions } \\
\end{array}$ & $\begin{array}{c}\text { Reducing } \\
\text { Conditions }\end{array}$ \\
\hline Radionuclide & \multicolumn{6}{|c|}{$K_{d}(\mathrm{ml} / g)$} \\
\hline Am & 5000 & 5000 & 5000 & 5000 & 500 & 500 \\
\hline $\mathrm{C}$ & 500 & 500 & 100 & 100 & 10 & 10 \\
\hline $\mathrm{Cl}$ & 5 & 5 & 1 & 1 & 0 & 0 \\
\hline I & 10 & 10 & 5 & 5 & 1 & 1 \\
\hline Lanthanides & 5000 & 5000 & 5000 & 5000 & 500 & 500 \\
\hline $\mathrm{Ni}$ & 100 & 100 & 100 & 100 & 10 & 10 \\
\hline $\mathrm{Nb}$ & 1000 & 1000 & 1000 & 1000 & 100 & 100 \\
\hline $\mathrm{Np}$ & 2000 & 5000 & 2000 & 5000 & 200 & 500 \\
\hline $\mathrm{Pu}$ & 5000 & 5000 & 5000 & 5000 & 500 & 500 \\
\hline $\mathrm{Ra}$ & 100 & 100 & 100 & 100 & 100 & 100 \\
\hline $\mathrm{Sr}$ & 1 & 1 & 3 & 3 & 3 & 5 \\
\hline Tc & 0 & 1000 & 0 & 1000 & 0 & 100 \\
\hline Th & 5000 & 5000 & 5000 & 5000 & 500 & 500 \\
\hline $\mathrm{U}$ & 1000 & 1000 & 1000 & 1000 & 100 & 100 \\
\hline
\end{tabular}

The above table does not include $\mathrm{Cs}$ or Eu, two nuclides of potential concern at Zion. Cs is known to have low sorption on cements. This is due in part to competition for sorption sites with other ions $(\mathrm{Na}$ and $\mathrm{K}$ ) that are released by the leaching from the concrete. Bradbury and Sarott (Bradbury 1995) provided $K_{d}$ estimates for Cs as 2 to $20 \mathrm{ml} / \mathrm{g}$ with the low value in Environment I. This is lower than the site-specific value for Cs at Zion. They also provided estimates for Eu (5000 to $1000 \mathrm{ml} / \mathrm{g}$ ) with Environment III with the lowest $\mathrm{K}_{\mathrm{d}}$ and $\mathrm{Cm}$ (5000 to $1000 \mathrm{ml} / \mathrm{g}$ ) with Environment III providing the least sorption (Bradbury, 1995). A recent study (Felipe-Sotello, 2012) measured $\mathrm{Kd}$ values for $\mathrm{Eu}$ at $66000 \mathrm{ml} / \mathrm{g}$. Other values for distribution coefficients in cementitious materials are provided in (Kaplan, 2008).

\section{Discussion}

Site-specific values are the most representative of the conditions that will occur at Zion after decommissioning and they will be recommended for use in groundwater dose assessment.

Although a final determination of the backfill material has not been made, it is likely that the backfill will contain a substantial amount of cementitious material. Examining the representative $\mathrm{K}_{\mathrm{d}}$ values for soils (Table 3) and cementitious systems (Table 4) it is clear that with the exception of $\mathrm{Cs}$ the cement $\mathrm{K}_{\mathrm{d}}$ values are greater than for soil systems. The $\mathrm{K}_{\mathrm{d}}$ value selected is meant to provide a conservative assessment of dose to the groundwater pathway. For this reason, with the exception of $\mathrm{H}$ and Tc literature soil $\mathrm{K}_{d}$ values will be recommended for the assessment when site-specific values are not available. To increase the degree of confidence 
that a conservative value has been selected the $25^{\text {th }}$ percentile $\mathrm{K}_{\mathrm{d}}$ from either the NRC or Sheppard reports will be used. For Tc the sand $K_{d}$ in Table 3 is less than 0.1 . The cementitious oxidizing conditions $\mathrm{K}_{\mathrm{d}}$ is zero in Table 4 . The soil $\mathrm{K}_{\mathrm{d}}$ is rounded to zero to ensure conservatism. The same will be done for the Table $3 \mathrm{H} \mathrm{K}_{\mathrm{d}}$ as a conservative assumption.

For one nuclide, $\mathrm{Sb}-125$, the IAEA median value was lower than the $25^{\text {th }}$ percentile value on the NRC distribution. No standard deviation was reported in the Sheppard data. For this reason, the IAEA value is recommended as the appropriate value for screening calculations for Sb-125.

The recommended values for the basement fill model are either site-specific or values measured in soil. The $\mathrm{K}_{\mathrm{d}}$ values in a cement environment for elements other tan Cs, Tc and $\mathrm{H}$ are expected to be higher based on existing data. Thus, they should be appropriate for outside of the buildings in the surrounding soil with the exception of $\mathrm{H}$, Tc and Cs. Depending on the buffering capacity of the soil, time, and distance from the building, the chemical environment of the groundwater exiting the building may control the sorption of Cs. For this reason, the site-specific Kd for Cs in the cement environment should be used in the surrounding soils to provide a conservative estimate of groundwater concentration for dose assessment.

\section{Recommended Values}

The values in Table 5 are the minimum values found in any test for the site-specific case and the minimum values found from the reports cited in Table 3. These values are appropriate for maximizing the groundwater concentration and thereby predicted dose. For intruder scenarios or scenarios where the backfill is used as gardening soils, a higher value of $\mathrm{K}_{\mathrm{d}}$ would be recommended for maximizing the predicted dose in those cases. 
Table 5 Recommended $K_{d}$ values to be used in the basement fill model.

\begin{tabular}{|c|c|c|c|}
\hline Radionuclide & $\begin{array}{l}\text { Half Life } \\
\text { (years) }\end{array}$ & $\begin{array}{l}\text { Recommended } \\
\text { Basement Fill } \\
\mathrm{K}_{\mathrm{d}} \mathrm{ml} / \mathrm{g}\end{array}$ & Reference $^{1}$ \\
\hline $\mathrm{H}-3$ & $1.24 \mathrm{E}+01$ & 0 & 2 \\
\hline$C-14$ & $5.73 E+03$ & 1.2 & NRC, 2000 \\
\hline Fe-55 & $2.70 \mathrm{E}+00$ & 2857 & Site-Specific \\
\hline $\mathrm{Ni}-59$ & $7.50 E+04$ & 62 & Site Specific \\
\hline Co-60 & $5.27 E+00$ & 223 & Site Specific \\
\hline $\mathrm{Ni}-63$ & $9.60 \mathrm{E}+01$ & 62 & Site Specific \\
\hline Sr-90 & $2.91 E+01$ & 2.3 & Site Specific \\
\hline $\mathrm{Nb}-94$ & $2.03 E+04$ & 45 & NRC, 2000 \\
\hline Tc-99 & $2.13 E+05$ & 0 & 2 \\
\hline Ag-108m & $1.27 \mathrm{E}+02$ & 27 & Sheppard, 1990 \\
\hline Sb-125 & $2.77 \mathrm{E}+00$ & 17 & IAEA, 2010 \\
\hline Cs-134 & $2.06 \mathrm{E}+00$ & 45 & Site Specific \\
\hline Cs-137 & $3.00 \mathrm{E}+01$ & 45 & Site Specific \\
\hline Pm-147 & $2.62 E+00$ & 95 & NRC, 2000 \\
\hline Eu-152 & $1.33 \mathrm{E}+01$ & 96 & $\mathrm{NRC}, 2000$ \\
\hline Eu-154 & $8.80 \mathrm{E}+00$ & 95 & $\mathrm{NRC}, 2000$ \\
\hline Eu-155 & $4.96 \mathrm{E}+00$ & 95 & NRC, 2000 \\
\hline $\mathrm{Np}-237$ & $2.14 \mathrm{E}+06$ & 1 & Sheppard, 1990 \\
\hline Pu-238 & $8.77 E+01$ & 174 & Sheppard, 1990 \\
\hline Pu-239/240 & $2.41 E+04$ & 174 & Sheppard, 1990 \\
\hline Pu-241 & $1.44 \mathrm{E}+01$ & 174 & Sheppard, 1990 \\
\hline Am-241 & $4.32 \mathrm{E}+02$ & 177 & NRC, 2000 \\
\hline Am-243 & $7.38 \mathrm{E}+03$ & 177 & $\mathrm{NRC}, 2000$ \\
\hline $\mathrm{Cm}-243 / 244$ & $2.85 \mathrm{E}+01$ & 891 & Sheppard, 1990 \\
\hline
\end{tabular}

${ }^{\text {T }}$ Values from NRC, 2000 or Sheppard, 1990 are the $25^{\text {th }}$ percentile values on the cumulative distribution function.

$225^{\text {th }}$ percentile value was less than 0.1 and was rounded down to 0 . 


\section{References}

Baes, C.F., and R.D. Sharp, (1983). A proposal for Estimation of Sol Leaching and Leaching Constants for Use in Assessment Models, ” J. Environ. Qual., Vol. 12, No. 1, 1983. Pp 17-28.

Besson, J.W. (2013). Humboldt Bay Power Plant License Termination Plan Revision 0 Chapter 6 Compliance with the Radiological Criteria May 2013, ENG-HB-003, Rev 0. Bartlett, Plymouth, MA.

Dionne, B.J., (2009). Calculation of Enrico Fermi 1 Derived Concentration Guideline Levels for Soil, ENG 004, Rev 1., Bartlett, Plymouth, MA

Environmental Protection Agency, (2004). Understanding Variation in Partition Coefficient, Kd Values, United States Office of Air and Radiation EPA 402-R-04-002C, Vol 1 - 3.

Felipe-Sotelo, M., Hinchliff, J., Evans, N., Warwick, P. and Read, D. (2012). Sorption of radionuclides to a cementitious backfill material under near-field conditions, Mineralogical Magazine, December 2012, Vol. 76(8), pp. 3401-3410.

International Atomic Energy Agency (IAEA, 2010). "handbook of Parameter Values for the Prediction of Radionuclide Transfer in Terrestrial and Freshwater Environments", Technical Report Series No. 472., International Atomic Energy Agency, Vienna, Austria.

Kaplan, D.J. Roberts, K., Coates, J., Sigegried, M., and Serkiz, S., 2008. "Saltstone and concrete interactions with radionuclides sorption $\left(K_{d}\right)$, desorption, and reduction capacity measurements", SRNS-STI-2008-00045, Savannah River National laboratory, Savannah River, SC.

Kay, J.A. (2004). “Yankee Nuclear Plant Station License Termination Plan,” Yankee Atomic Electric Company, MA.

Krupka, K. M. and R. J. Serne. (1998). Effects on Radionuclide Concentrations by Cement/Ground-Water Interactions in Support of Performance Assessment of Low-Level Radioactive Waste Disposal Facilities. NUREG/CR-6377 (PNNL-11408), Pacific Northwest, National Laboratory, Richland, Washington.

Milian, L., T. Sullivan (2014). Sorption $\left(K_{d}\right)$ measurements on Cinder Block and Grout in Support of Dose Assessments for Zion Nuclear Station Decommissioning, Brookhaven National Laboratory Report to ZionSolutions, April 2014 (Draft).

Ochs, M., Pointeau, I. and Giffaut, E. (2006). Caesium sorption by hydrated cement as a function of degradation state: Experiments and modelling. Waste Management, 26, 725_732.

Sheppard, M. and Thibault, D.H., 1990. "Default Soil Solid/Liquid Partition Coefficients, $\mathrm{K}_{d} \mathrm{~S}$, For Four Major Soil types: A Compendium”, Health Physics, Vol. 59, No. 4, pp. 471-481, Oct, 1990. 
U.S. Nuclear Regulatory Commission, (NRC, 2000). Development of Probabilistic RESRAD 6.0 and RESRADBUILD 3.0 Computer Codes, NUREG/CR-6697, U.S. Nuclear Regulatory Commission, December 2000.

U.S. Department of Energy West Valley Demonstration Project, (DOE, 2009). Phase 1 Decommissioning Plan for the West Valley Demonstration, Appendix C Rev 2., Department of Energy.

Yim, S.P, T.M. Sullivan, and L. Milian, Sorption $(\mathrm{Kd})$ measurements in Support of Dose Assessments for Zion Nuclear Station Decommissioning, Brookhaven National Laboratory Report to ZionSolutions, December 12, 2012.

Yu, C., Loureiro, C., Cheng, J.-J., Jones, Y.Y., Wang, Y.P. Chia, and E. Faillace, (1993). "Data Collection Handbook to Support Modeling the Impacts of Radioactive Material in Soil," ANL/EAIS-8, Argonne National Laboratory, Argonne, IL. 